\title{
Selective Expression of a Dominant-Negative Type I $\alpha$ PKA Regulatory Subunit in Striatal Medium Spiny Neurons Impairs Gene Expression and Leads to Reduced Feeding and Locomotor Activity
}

\author{
Linghai Yang, Merle L. Gilbert, Ruimao Zheng, and G. Stanley McKnight \\ Department of Pharmacology, University of Washington, Seattle, Washington 98195
}

\begin{abstract}
Striatal medium spiny neurons (MSNs) mediate many of the physiological effects of dopamine, including the regulation of feeding and motor behaviors. Dopaminergic inputs from the midbrain modulate MSN excitability through pathways that involve cAMP and protein kinase A (PKA), but the physiological role of specific PKA isoforms in MSN neurons remains poorly understood. One of the major PKA regulatory $(\mathrm{R})$ subunit isoforms expressed in MSNs is $\mathrm{RII} \beta$, which localizes the PKA holoenzyme primarily to dendrites by interaction with AKAP5 and other scaffolding proteins. However, RI (RI $\alpha$ and RI $\beta$ ) subunits are also expressed in MSNs and the RI holoenzyme has a weaker affinity for most scaffolding proteins and tends to localize in the cell body. We generated mice with selective expression of a dominant-negative RI subunit $(\mathrm{RI} \alpha \mathrm{B})$ in striatal MSNs and show that this dominant-negative RI $\alpha \mathrm{B}$ localizes to the cytoplasm and specifically inhibits type I PKA activity in the striatum. These mice are normal at birth; however, soon after weaning they exhibit growth retardation and the adult mice are hypophagic, lean, and resistant to high-fat diet-induced hyperphagia and obesity. The RI $\alpha \mathrm{B}-$ expressing mice also exhibit decreased locomotor activity and decreased dopamine-regulated CREB phosphorylation and c-fos gene expression in the striatum. Our results demonstrate a critical role for cytoplasmic RI-PKA holoenzyme in gene regulation and the overall physiological function of MSNs.
\end{abstract}

Key words: dopamine; feeding; locomotion; PKA; striatum; subcellular localization

\section{Introduction}

Medium spiny neurons (MSNs) in the striatum receive glutamatergic inputs from other brain regions including the cortex, thalamus, amygdala, and hippocampus. Dopaminergic innervation from the midbrain modulates the activity of MSNs and controls many fundamental behaviors such as locomotion, feeding, and goal-directed learning (Palmiter, 2008). The effects of dopamine are mediated principally by two types of dopamine receptors, D1R and D2R, which are highly enriched in distinct populations of MSNs in the striatum, although there is a small degree of coexpression (Valjent et al., 2009).

Dopamine receptors are part of the large family of GPCRs: D1R (dopamine receptor 1) is $\mathrm{G}_{\mathrm{s} / \mathrm{olf}}$-coupled and stimulates adenylyl cyclase and cAMP production while D2R (dopamine receptor 2 ) is $\mathrm{G}_{\mathrm{i}}$-coupled and inhibits adenylyl cyclase activity and

\footnotetext{
Received Aug. 12, 2013; revised Jan. 31, 2014; accepted Feb. 25, 2014.

Author contributions: L.Y., M.L.G., R.Z., and G.S.M. designed research; L.Y., M.L.G., and R.Z. performed research; L.Y., R.Z., and G.S.M. analyzed data; L.Y. and G.S.M. wrote the paper.

This work was supported by National Institutes of Health GM032875. We greatly appreciate the technical assistance of Thong Su in these studies and we thank Dr. Paul Amieux for his advice throughout this study.

The authors declare no competing financial interests.

Correspondence should be addressed to G. Stanley McKnight, Department of Pharmacology, University of Washington, 1959 Northeast Pacific Street, Box 357280, Seattle, WA 98195. E-mail: mcknight@u.washington.edu.

DOI:10.1523/JNEUROSCI.3460-13.2014

Copyright $\odot 2014$ the authors $\quad 0270-6474 / 14 / 344896-09 \$ 15.00 / 0$
}

cAMP production. The effects of dopamine on MSNs are thought to be mediated in part by protein kinase A (PKA)-dependent phosphorylation of receptors, ion channels, transcription factors, and other signaling proteins (Greengard, 2001). However, cAMP effectors such as ion channels and exchange proteins (Epacl and Epac2) may also be involved in dopamine-dependent signaling in MSNs (Beaulieu and Gainetdinov, 2011). Signaling pathways independent of cAMP have also been suggested to mediate some of the physiological effects of dopamine (Beaulieu et al., 2007). Thus the precise contribution of PKA to dopamine signaling in MSNs remains to be determined.

PKA holoenzyme is inactive and composed of a regulatory $(\mathrm{R})$ subunit dimer and two catalytic $(\mathrm{C})$ subunits that are released upon cAMP binding to the two binding sites ( $A$ and $B$ ) on each $R$ subunit. RII $\beta$ is the major isoform of PKA expressed in MSNs (Brandon et al., 1998) and the RII $\beta$-PKA holoenzyme is localized to dendrites by binding to AKAP5 and microtubule-associated protein 2 (MAP2; Weisenhaus et al., 2010). Disruption of RII $\beta$ expression leads to a dramatic downregulation of total PKA activity in the striatum and a partial compensatory increase in RI subunits (both RI $\alpha$ and RI $\beta$ ) (Brandon et al., 1998). The type I $(\mathrm{RI} \alpha / \mathrm{RI} \beta)$ PKA does not bind with high affinity to AKAP5 or MAP2 and localizes to the cell body in neurons. We previously cloned mutant RI $\alpha$ subunits with the ability to suppress $\mathrm{C}$ subunit activity in the presence of physiological levels of cAMP 

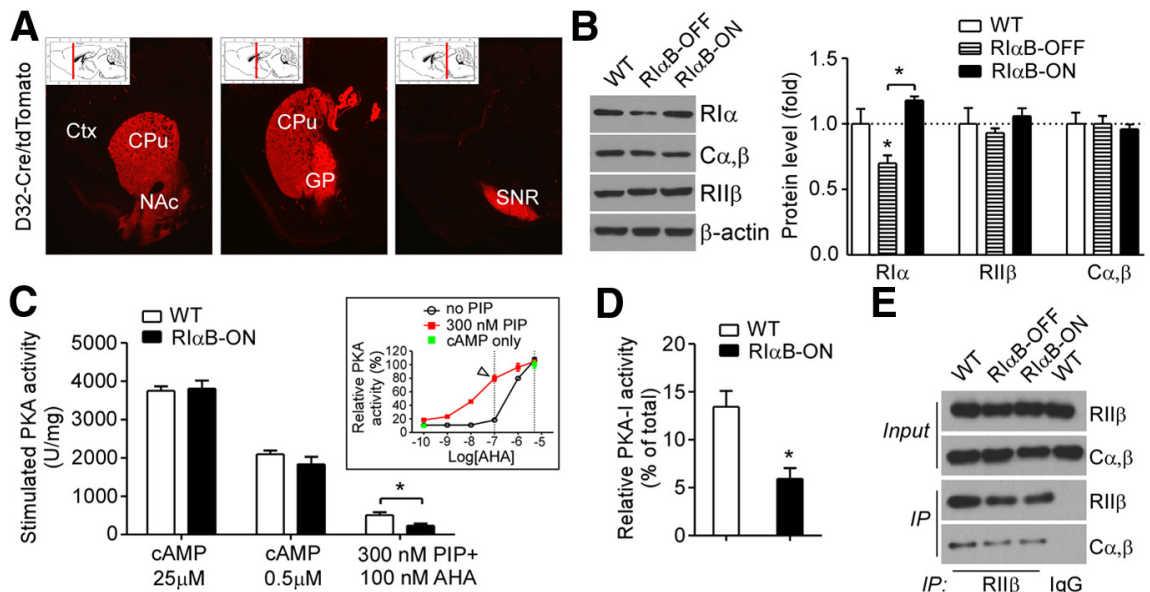

D

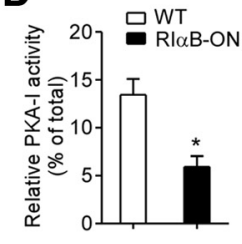

E

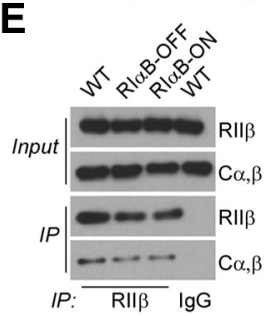

G

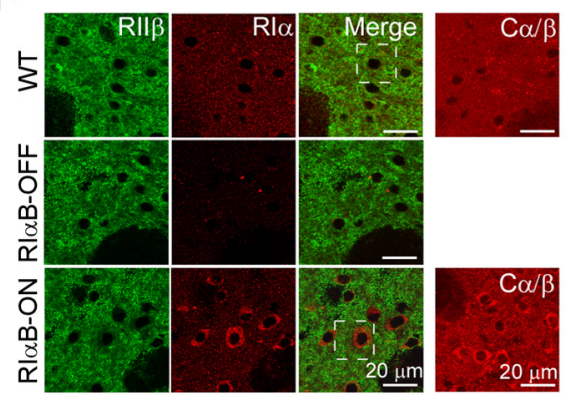

$\mathrm{RI} \alpha \mathrm{B}-\mathrm{OFF}$ and the D32-Cre/Prkarla $a^{R I \alpha B / W T}$ as $\mathrm{RI} \alpha \mathrm{B}-\mathrm{ON}$ to denote whether the $\mathrm{RI} \alpha \mathrm{B}$ mutant allele is silent or expressed. The D32-Cre and $\mathrm{RI} \alpha \mathrm{B}-\mathrm{OFF}$ animals were indistinguishable from their wild-type littermates in appearance, body weight, fat content, and locomotor activity and were used as controls. All procedures were approved by the School of Medicine Institutional Animal Care and Use Committee at the University of Washington.

Phenotypic studies. Mice were housed with free access to regular food and water. Body weight was measured weekly. Food intake was measured daily in 12- to 16-week-old mice for 2 weeks and averaged. Resting oxygen consumption $\left(\mathrm{VO}_{2}\right)$ was measured as described previously (Nolan et al., 2004). High-fat diet (Research Diets \#D12492) was fed from 16 to 20 weeks of age and control groups were fed with regular chow for the same period. At the end of the growth curve study, mice were killed, anal-nasal length was measured, fat pads were weighed, and sera were collected for leptin assay by ELISA (Millipore, catalog \#EZML$82 \mathrm{~K})$. For food-preference studies, mice had access to both chow and high-fat diet simultaneously from separate food chambers and intake of either food was measured daily for $7 \mathrm{~d}$.

Behavioral studies. Locomotor activity and rotarod performance were measured in mice at $12-16$ weeks of age. Briefly, mice were housed individually in a beam-break locomotor activity cage (San Diego Instruments) for $3 \mathrm{~d}$. Ambulations were scored as interruption of consecutive beams. To examine motor coordination, mice were tested on an accelerating rotarod $(4-30 \mathrm{rpm}$ over the course of $5 \mathrm{~min}$ ) and latency to fall was recorded automatically. To test the effects of D-amphetamine and haloperidol on locomotion, mice were individually placed in the locomotor cage for a $2 \mathrm{~h}$ habituation period and then injected intraperitoneally with vehicle or drug and ambulations were recorded $20 \mathrm{~min}$ later for another $2 \mathrm{~h}$. Vehicle and varying doses of drugs were tested every other day and drugs were injected from low to high dosages.

(Clegg et al., 1987; Steinberg et al., 1991). The RI $\alpha$ B mutation contains a single amino acid change (G324D) in the C-terminal cAMP-binding site (site B), a mutation that increases the $K_{\mathrm{a}}$ for activation of the RI $\alpha$ subunit $>100$-fold (Woodford et al., 1989). We have generated conditional mice in which the $\mathrm{RI} \alpha \mathrm{B}$ mutation was introduced into one allele of the Prkarla gene and its expression was Cre recombinase-dependent (Howe et al., 2006; Willis et al., 2011). In the present study we selectively expressed the RI $\alpha \mathrm{B}$ mutant in striatal MSNs to inhibit selectively the cytoplasmic type I PKA without affecting the dendritic RII $\beta$-PKA. After weaning these mice exhibited growth retardation, impaired locomotor abilities, and disrupted feeding behavior suggesting a unique and critical role for the cytoplasmic type I PKA in MSN function.

\section{Materials and Methods}

Mice. All mice were bred into a C57BL/6J background. DARPP-32 ${ }^{\mathrm{Cre}}$ / $\mathrm{RI} \alpha \mathrm{B}$ mice were obtained by crossing heterozygous DARPP-32 ${ }^{\mathrm{Cre}}$ (D32Cre) transgenic mice (Bogush et al., 2005) to Prkarla ${ }^{R I \alpha B / W T}$ (RI $\alpha \mathrm{B}$ ) mice (Willis et al., 2011). We refer to the Cre-negative Prkarla ${ }^{R I \alpha B / W T}$ as
Kinase assays. PKA activity was measured as described previously (Howe et al., 2006). The RI-PKA-specific cAMP analogs 6-Bnz-8-PIPcAMP (specific for A site) and 2-Cl-8-AHA-cAMP (specific for B site) were from Biolog. Striatal protein extracts from ad libitum fed 12- to 16-week-old male mice were prepared in ice-cold kinase buffer $(20 \mathrm{~mm}$ Tris, pH 7.5, 250 mм sucrose, 0.1 mм EDTA, 0.5 mm EGTA, 1\% Triton $\mathrm{X}-100,10 \mathrm{~mm}$ dithiothreitol, $1 \mu \mathrm{g} / \mathrm{ml}$ leupeptin, $3 \mu \mathrm{g} / \mathrm{ml}$ aprotinin, ' $40 \mu \mathrm{g} / \mathrm{ml}$ soybean trypsin inhibitor, $0.5 \mathrm{~mm}$ 4-(2-aminoethyl) benzenesulfonyl fluoride) using a dounce homogenizer followed by brief sonication. Protein extracts were incubated at $37^{\circ} \mathrm{C}$ for $5 \mathrm{~min}$ to deplete endogenous cAMP and then snap frozen in liquid nitrogen and stored at $-80^{\circ} \mathrm{C}$. Protein extracts were thawed on ice and BCA assays (catalog \#23227; Pierce) were performed to determine protein concentration. All samples were diluted to $1 \mathrm{mg} / \mathrm{ml}$ protein and $10 \mu \mathrm{l}$ of each sample was used in a $50 \mu \mathrm{l}$ final reaction volume. Kinase assays were performed in duplicate using the PKA substrate peptide Kemptide (Leu-Arg-ArgAla-Ser-Leu-Gly) in the presence or absence of either cAMP or a combination of the RI-analogs (300 nM 6-Bnz-8-PIP-cAMP + $100 \mathrm{~nm}$ 2-Cl-8-AHA-cAMP), respectively. Background kinase activity measured in the presence of $4 \mu \mathrm{g} / \mathrm{ml}$ of the specific PKA inhibitor, PKI, was subtracted. 
Western blot analysis. Microdissected striatum was homogenized in lysis buffer $(20 \mathrm{~mm}$ Tris-Cl, pH 7.5, 100 mu NaCl, 2 mm EDTA, 1\% Triton X-100, 0.5\% deoxycholic acid) supplemented with protease and phosphatase inhibitors (catalog \#P8340 and \#P2850; Sigma), sonicated and cleared by centrifugation $(10,000 \times g, 10 \mathrm{~min})$. Western procedure was previously described (Zheng et al., 2013). Primary antibodies: anti-RII $\beta$ (BD Transduction Laboratories; \#610626), anti- $\beta$-actin (Sigma; \#A5316), anti-RI $\alpha$ (BD Transduction Laboratories; \#610610), and anti-C $\alpha, \beta$ (a gift from Susan Taylor, University of California San Diego).

Histology and immunohistochemistry. Adult mice were anesthetized with pentobarbital and transcardially perfused with PBS followed by ice-cold PBS-buffered 4\% paraformaldehyde. Histology and immunohistochemistry of the brain were described previously (Zheng et al., 2013). Primary antibodies: anti-RII $\beta$ (BD Transduction Laboratory; \#610626), anti-RI $\alpha$ (Cell Signaling Technology; \#5675), anti-c-fos (Santa Cruz Biotechnology; sc-7202), and antiphospho-CREB (S133; Cell Signaling Technology; \#9198).

Immunoprecipitation. Striatal tissue was homogenized at 1:10 (w/v) in ice-cold immunoprecipitation (IP) buffer ( $10 \mathrm{~mm}$ Tris- $\mathrm{HCl}, \mathrm{pH}$ 8.0, $100 \mathrm{~mm} \mathrm{NaCl}, 5$ mм EDTA, $5 \mathrm{~mm} \mathrm{NaF}$ ) containing $1.0 \%$ Triton $\mathrm{X}-100,0.5 \%$ deoxycholic acid, and $1 \times$ protease and phosphatase inhibitors (catalog \#P8340 and \#P2850; Sigma) and centrifuged $\left(10,000 \times g, 10 \mathrm{~min}\right.$ at $\left.4^{\circ} \mathrm{C}\right)$. The supernatant was collected and protein concentration was determined by BCA assay. The supernatant was diluted to $0.5 \mathrm{mg} / \mathrm{ml}$ protein with IP buffer containing $0.1 \%$ Triton $\mathrm{X}-100$ and $1 \times$ protease inhibitor cocktail. Anti-RII $\beta$ antibody was added and incubated overnight at $4^{\circ} \mathrm{C}$ followed by capture with $40 \mu \mathrm{l}$ of a $50 \%$ slurry of Protein $G$ magnetic beads (Dynabeads $\mathrm{H}$; Invitrogen) for $1 \mathrm{~h}$ at $4^{\circ} \mathrm{C}$. The beads were washed four times with lysis buffer containing $0.1 \%$ Triton X-100 and the immunoprecipitated proteins were eluted from the beads with $2 \times$ Laemmli sample buffer and boiled. The eluted samples were then separated by SDS-PAGE and assayed by Western blot.

Quantitative RT-PCR. We isolated total RNA from the hypothalamus using RNeasy Mini Kit (Qiagen\#74104). Brilliant II SYBR Green QRT-PCR 1-Step Master Mix was used for quantitative RT-PCR. Messenger RNA levels of Agrp, Npy, Pomc, dynorphin, enkephalin, and c-fos were compared between $\mathrm{RI} \alpha \mathrm{B}-\mathrm{ON}$ and control mice by normalization to $\beta$-actin mRNA content. Primers are as follows: Agrp, For: 5'tagatccacagaaccgcgagt- $3^{\prime}$ and Rev: $5^{\prime}$-gaagcggcagtagcacgta- $3^{\prime}$; Npy, For: $5^{\prime}$-ctccgctctgcgacactac- $3^{\prime}$ and Rev: $5^{\prime}$-agggtcttcaagccttgttct- $3^{\prime}$; Pomc, For: $5^{\prime}$-ctggagacgcccgtgtttc- $3^{\prime}$ and Rev: $5^{\prime}$-tggactcggctctggactg- $3^{\prime}$; dynorphin, For $5^{\prime}$-gtgcagtgaggattcaggatggg- $3^{\prime}$ and Rev $5^{\prime}$-gagcttggctagtgcactgtagc- $3^{\prime}$; enkephalin, For $5^{\prime}$-ctaaatgcacgtaccgcctggtt- $3^{\prime}$ and Rev $5^{\prime}$ cgatgttatcccaagggaactcg-3'; c-fos, For $5^{\prime}$-cgggtttcaacgccgacta- $3^{\prime}$ and Rev $5^{\prime}$-ttggcactagagacggacaga-3'; Actb, For: 5' -agtgtgacgttgacatccgta- $3^{\prime}$, Rev: $5^{\prime}$-gccagagcagtaatctccttct- $3^{\prime}$.

Statistics. Statistical analysis was performed using Prism GraphPad software. Data were analyzed by two-tailed Student's $t$ test, one-way ANOVA, or

C mean \pm SEM.
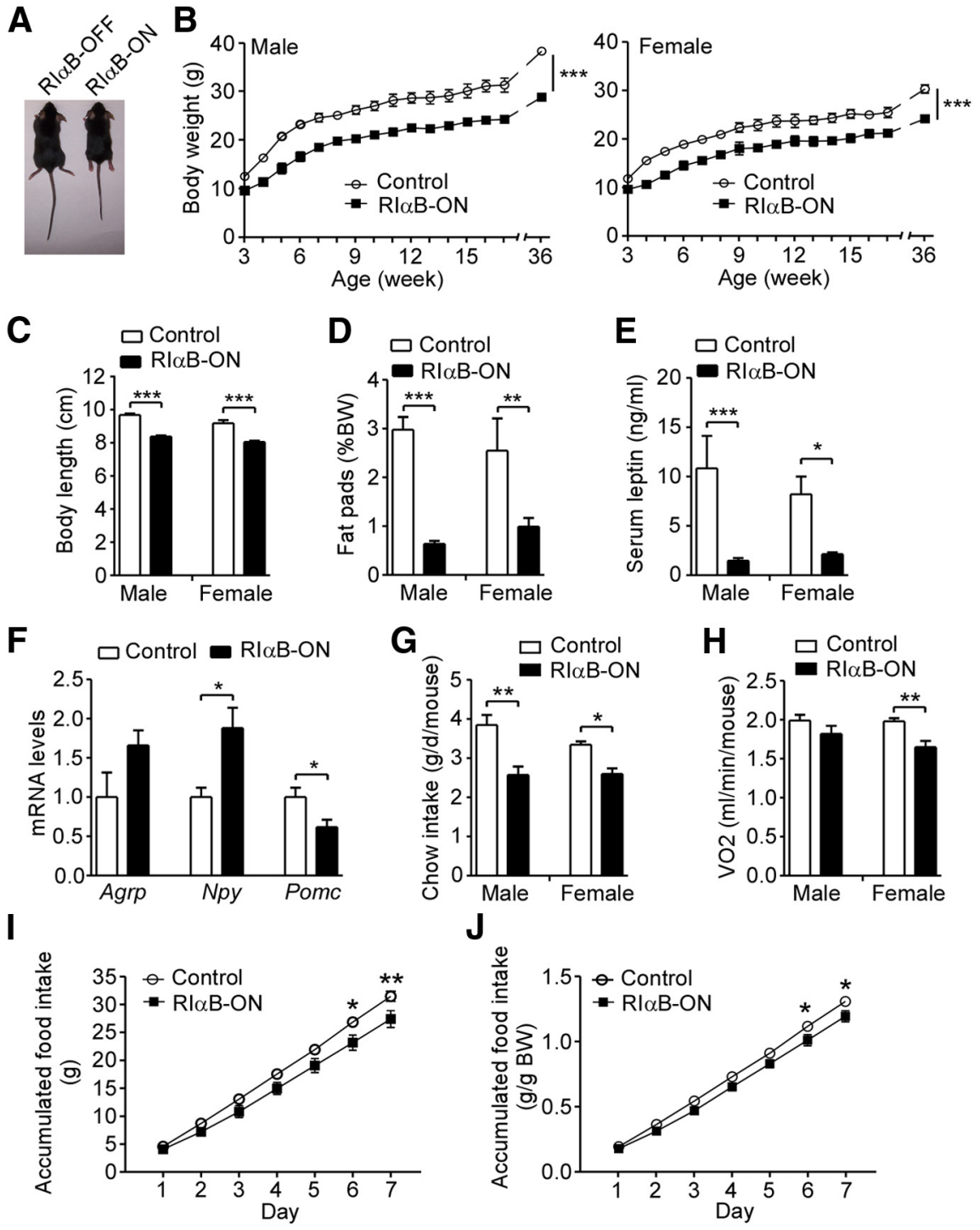

Figure 2. $\mathrm{Rl} \alpha \mathrm{B}$ expression in MSNs leads to growth retardation, hypophagia, and a lean phenotype. $\boldsymbol{A}$, Rl $\alpha \mathrm{B}-0 \mathrm{~N}$ mice (right) are small compared with their RI $\alpha$ B-OFF (left), D32-Cre, and WT (data not shown) littermates. Shown are 4-week-old females. $\boldsymbol{B}$ Growth curves of male and female control and Rl $\alpha \mathrm{B}-0 \mathrm{~N}$ mice on regular chow diet $\left(n=8-10\right.$ for each group; ${ }^{* *} p<0.001$ between genotypes by two-way ANOVA). The control groups include WT, D32-Cre, and RI $\alpha$ B-OFF mice. C, Body length (nasal-anal) of control and Rl $\alpha$ B-ON mice at 32-36 weeks of age ( $n=6-11$ for each group; $p<0.0001$ between genotypes). $D$, Weight of reproductive fat pads of control and RI $\alpha \mathrm{B}-0 \mathrm{~N}$ mice ( $n=8-12$ for each group; $p<0.0001$ between genotypes). $\boldsymbol{E}$, Serum leptin levels of male and female control and RI $\alpha$ B-ON mice ( $n=5-7$ for each group; $p<0.0001$ between genotypes). $F$, Hypothalamic mRNA levels of Agrp, Npy, and Pomc in control and Rl $\alpha$ B-ON mice ( $n=5-7$ males for each genotype; ${ }^{*} p<0.05$ by Student's $t$ tests). G, Food intake of age-matched male and female control and Rl $\alpha \mathrm{B}-0 \mathrm{~N}$ mice on regular chow diet $(n=11-16$ for each group; $p<0.001$ between genotypes). $\boldsymbol{H}$, Resting oxygen consumption of male and female control and Rl $\alpha \mathrm{B}-0 \mathrm{~N}$ mice $(n=6-8$ for each group; $p<0.01$ between genotypes). I, J, Accumulated food intake of body weight-matched male control $(n=8)$ and Rl $\alpha \mathrm{B}-0 \mathrm{~N}$ mice $(n=5)$ as measured by per mouse $(I)$ and per gram of body weight $(\boldsymbol{J}) ; p<0.0001$ between genotypes in both analyses. Two-way ANOVA for the effect of genotypes; ${ }^{*} p<0.05,{ }^{* *} p<0.01,{ }^{* * *} p<0.001$ by Bonferroni post-tests (C-E, G-J). Data are

two-way ANOVA when appropriate. In some analyses, ANOVA was followed by Bonferroni post-tests for multiple comparisons. In the locomotion responses to dopamine drugs, comparisons were performed using repeated-measures two-way ANOVA. Values are presented as means \pm SEM. Differences were considered significant at $p<0.05$.

\section{Results}

Striatum-specific expression of a dominant-negative PKA $\mathrm{RI} \alpha$ regulatory subunit

To partially inhibit the PKA in MSNs, we used an MSN-specific Darpp32-Cre transgenic (D32-Cre) to turn on a silenced allele 
A
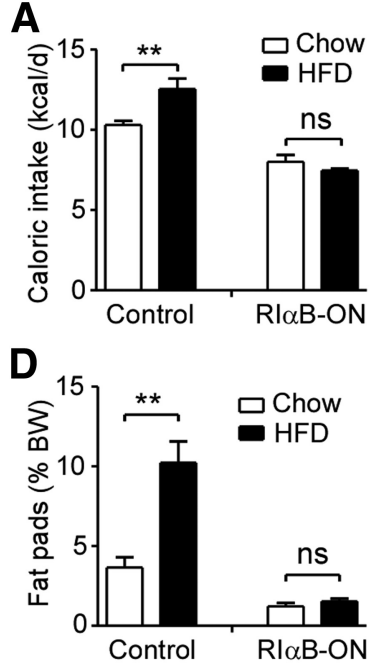

F

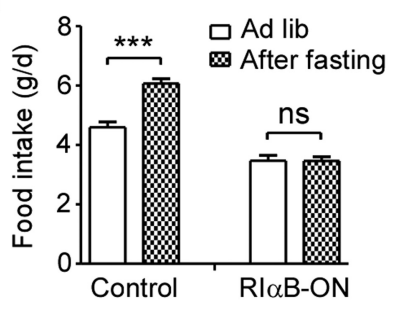

B

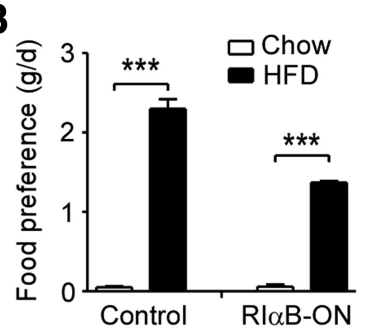

E

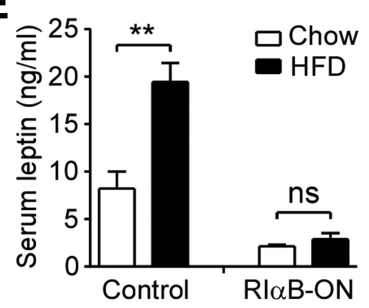

G

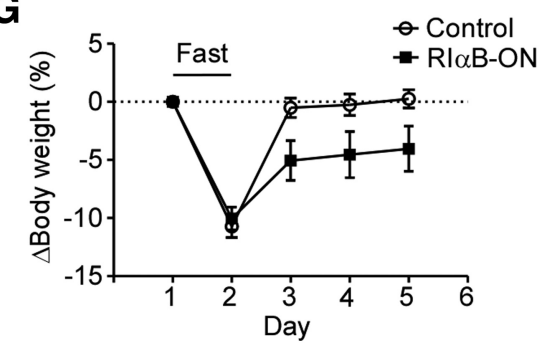

Figure 3. Rl $\alpha \mathrm{B}-0 \mathrm{~N}$ mice are resistant to diet-induced hyperphagia and obesity and have defective compensatory feeding after fasting. $\boldsymbol{A}$, Calorie intake of control and $\mathrm{Rl} \alpha \mathrm{B}-\mathrm{ON}$ mice on chow and high-fat diet. $\boldsymbol{B}, \mathrm{Rl} \alpha \mathrm{B}-\mathrm{ON}$ mice and WT mice have similar preferences for high-fat diet compared with chow diet. Mice were given chow and high-fat diets simultaneously and intakes of each were measured. C, Body weight changes of control and Rl $\alpha$ B-ON mice after 4 weeks of feeding on a high-fat diet $(n=5$ each genotype). $\boldsymbol{D}, \boldsymbol{E}$, Reproductive fat pad weight $(\boldsymbol{D})$ and serum leptin levels $(\boldsymbol{E})$ of control and Rl $\alpha \mathrm{B}-0 \mathrm{~N}$ mice on chow $(n=6-7$ each genotype) and high-fat diet ( $n=5$ each genotype). $\boldsymbol{F}$, Food (chow) intake ad libitum and after $24 \mathrm{~h}$ fasting of control $(n=6)$ and $\mathrm{Rl} \alpha \mathrm{B}-\mathrm{ON}$ mice $(n=7)$. G, Body weight changes in response to fasting and re-feeding in control $(n=6)$ and Rl $\alpha \mathrm{B}-0 \mathrm{~N}$ mice $(n=$ $7, p<0.01$ between genotypes by tw0-way ANOVA). ${ }^{*} p<0.05,{ }^{* *} p<0.01,{ }^{* * *} p<0.001$ by Student's $t$ tests. Data are mean \pm SEM.

of the Prkarla gene that encodes a dominant-negative mutation in the C-terminal cAMP binding site of $\mathrm{RI} \alpha$. The Crerecombinase inducible dominant-negative PKA subunit $(\mathrm{RI} \alpha \mathrm{B})$ mouse line was generated and characterized previously (Willis et al., 2011). The RI $\alpha \mathrm{B}$ mice that have not been crossed to a Cre recombinase-expressing line only express the wild-type (WT) allele and therefore have the same male reproductive deficiency as the RI $\alpha$ heterozygote mice that we have characterized previously (Veugelers et al., 2004; Burton et al., 2006). We created mice with striatum-specific $\mathrm{RI} \alpha \mathrm{B}$ expression by mating a female $\mathrm{RI} \alpha \mathrm{B}$ heterozygote to a D32-Cre transgenic male. The specificity of D32Cre expression in mouse brain was verified by crossing the Crerecombinase-expressing driver line to a tdTomato reporter mouse (Madisen et al., 2010). In D32-Cre/tdTomato mice, the expression of tdTomato in brain was restricted to cell bodies, dendrites, and axonal terminals of striatal MSNs (Fig. 1A), which is consistent with a previous report using $\beta$ galactosidase as the reporter for D32-Cre (Bogush et al., 2005). Further analysis using a lox-stop RII $\beta$ allele as a reporter confirmed that the D32-Cre was not expressed in any other tissues that express RII $\beta$ including white adipose, brown adipose, thyroid, adrenal, or pituitary (Zheng et al., 2013) Western blot analysis of striatal extracts from WT, RI $\alpha$ B-OFF, and RI $\alpha$ B-ON (D32-Cre/RI $\alpha \mathrm{B}$ ) mice revealed that $\mathrm{RI} \alpha$ protein levels in the $\mathrm{RI} \alpha \mathrm{B}-\mathrm{ON}$ mice were comparable to WT and significantly higher

than $\mathrm{RI} \alpha \mathrm{B}-\mathrm{OFF}$ mice that express only one RI $\alpha$ allele (Fig. 1B). This indicated that the silent $\mathrm{RI} \alpha \mathrm{B}$ allele was efficiently activated by Cre-recombinase in $\mathrm{RI} \alpha \mathrm{B}-\mathrm{ON}$ mice. However, RII $\beta$ and $\mathrm{C} \alpha$ protein levels were similar in all three genotypes indicating an absence of compensatory changes (Fig. 1B).

To determine whether the type I PKA (RI-PKA) was specifically inhibited in the striatum, we measured type I PKA activation specifically using the cAMP analogs 6-Bnz-8-PIP-cAMP (RI-A site selective) and 2-Cl-8-AHA-cAMP (RI-B site selective). A combination of these two analogs synergistically activates the type I, RI $\alpha$ PKA (Huseby et al., 2011). When we used $300 \mathrm{~nm}$ 6-Bnz-8-PIP-cAMP and $100 \mathrm{~nm}$ 2-Cl-8-AHA-cAMP in an extract from RII $\beta$ KO brown fat that expresses almost exclusively RI $\alpha$-PKA, the analog combination activated $\sim 76 \%$ of the total $\mathrm{RI} \alpha$ PKA (Fig. 1C, inset). Striatal extracts from WT and RI $\alpha$ B-ON mice displayed the same total PKA activity in the presence of high $(25 \mu \mathrm{M})$ cAMP, which would be expected to activate all $\mathrm{PKA}$ including the RI $\alpha$ B-PKA (Fig. 1C; Woodford et al., 1989). In the presence of low $(0.5 \mu \mathrm{M})$ cAMP, RI $\alpha$ B expression inhibited the activation of total PKA by $\sim 10 \%$, but the difference was not significant in Figure $1 C$. However, the RI $\alpha$-specific analogs demonstrated that type I PKA activation was decreased by $56 \%$ in $\mathrm{RI} \alpha \mathrm{B}-\mathrm{ON}$ extracts (Fig. 1C). The analogs activated $13.5 \pm 1.6$ and $5.9 \pm 1.1 \%$ of total PKA in

WT and $\mathrm{RI} \alpha \mathrm{B}-\mathrm{ON}$ extracts, respectively (Fig. 1D). Based on our observation that the RI-analogs activated $\sim 76 \%$ of total RI-PKA (Fig. $1 C$, inset), we estimated that $\sim 18 \%$ of striatal PKA is RI-PKA. Since the RII $\beta$ subunit is localized to dendrites by AKAP5 in the MSNs, we reasoned that the RII $\beta$ PKA holoenzyme might be largely unaffected by the presence of the mutant RI $\alpha$, which has negligible affinity for AKAP5 (Herberg et al., 2000) and is expected to be cytoplasmic. To test this we immunoprecipitated $\mathrm{RII} \beta$ from control and $\mathrm{RI} \alpha \mathrm{B}-\mathrm{ON}$ striatum and examined the coimmunoprecipitation of $\mathrm{C}$ subunit. The expression of $\mathrm{RI} \alpha \mathrm{B}$ did not decrease the level of $\mathrm{C}$ subunit that was in a holoenzyme with RII $\beta$ (Fig. $1 E$ ). The subcellular localization of RII $\beta$ and the mutant RI $\alpha \mathrm{B}$ was examined by immunohistochemistry. RII $\beta$ was present in dendrites and unchanged in the $\mathrm{RI} \alpha \mathrm{B}-\mathrm{ON}$ striatum, whereas the expressed dominant-negative $\mathrm{RI} \alpha \mathrm{B}$ is predominately in the cell body (Fig. $1 F$ ). As a consequence, more $\mathrm{C}$ subunit was observed in the cell body in $\mathrm{RI} \alpha \mathrm{B}-\mathrm{ON}$ striatum compared with WT control (Fig. $1 F$ ), suggesting the presence of an $\mathrm{RI} \alpha \mathrm{B}-\mathrm{C}$ complex, which is resistant to cAMP-induced dissociation and subsequent degradation. Images with increased magnification showed that $\mathrm{RII} \beta$ and $\mathrm{RI} \alpha(\mathrm{RI} \alpha \mathrm{B})$ had punctate distribution and were localized to discrete compartments in MSNs, with much more $\mathrm{RI} \alpha$ staining in the soma in $\mathrm{RI} \alpha \mathrm{B}-\mathrm{ON}$ mice (Fig. $1 G$ ). The inhibition of PKA activity is therefore likely to exert its primary effect on PKA-dependent events in the cell body of MSNs. 


\section{$\mathrm{RI} \alpha \mathrm{B}-\mathrm{ON}$ mice are lean and growth retarded}

$\mathrm{RI} \alpha \mathrm{B}-\mathrm{ON}$ mice were born at expected Mendelian ratios and, during the first two postnatal weeks, were indistinguishable from their littermates. However, growth retardation and reduced body weight became obvious at the end of the third postnatal week. Reduced body length was observed in RI $\alpha \mathrm{B}-\mathrm{ON}$ mice (Fig. $2 \mathrm{~A}, \mathrm{C}$ ). This growth retardation is strikingly similar to the D1 receptor $\mathrm{KO}$ mice, which also demonstrate growth retardation from the third postnatal week (Drago et al., 1994). After weaning, the RI $\alpha \mathrm{B}-\mathrm{ON}$ mice gained weight on a regular chow diet but exhibited a $20-25 \%$ reduction in body weight compared with control mice (Fig. $2 B)$. The control mice include D32-Cre and $\mathrm{RI} \alpha \mathrm{B}-\mathrm{OFF}$ mice, which are indistinguishable from their WT littermates.

Examination of specific tissues during postnatal development revealed that $\mathrm{RI} \alpha \mathrm{B}-\mathrm{ON}$ mice had a greatly reduced content of white adipose tissue (Fig. 2D). Consistent with the reduced amount of fat, $\mathrm{RI} \alpha \mathrm{B}-\mathrm{ON}$ mice had significantly lower serum leptin (Fig. 2E). Leptin regulates food intake and energy expenditure by binding to the leptin receptor in the hypothalamus and thus promoting expression of the anorexigenic peptide POMC while at the same time inhibiting the expression of the orexigenic peptides, (agouti-related neuropeptide) AgRP and NPY (Myers et al., 2008). We examined mRNA levels for Npy, Agrp, and Pomc in the hypothalamus of mice fed ad libitum. Consistent with their reduced leptin levels, $\mathrm{RI} \alpha \mathrm{B}-\mathrm{ON}$ mice had increased expression of Agrp and Npy and decreased expression of Pomc compared with control mice (Fig. $2 F$ ) demonstrating that $\mathrm{RI} \alpha \mathrm{B}-\mathrm{ON}$ mice are sensing their reduced leptin levels. RI $\alpha \mathrm{B}-\mathrm{O}$ mice consume less chow (Fig. 2G) and energy expenditure as measured by oxygen consumption was significantly reduced in females and trended lower in males (Fig. $2 \mathrm{H}$ ). This is not surprising since the $\mathrm{RI} \alpha \mathrm{B}-\mathrm{ON}$ mice also display a significant decrease in body size. To address whether RI $\alpha \mathrm{B}-\mathrm{ON}$ mice are hypophagic independent of body size we used weight-matched mice (body weight: control $24.1 \pm$ 0.6 g; RI $\alpha$ B-ON $23.0 \pm 1.0$ g). RI $\alpha$ B-ON mice ate $\sim 10 \%$ less (weekly food intake: $1.31 \pm 0.03$ for control mice vs $1.19 \pm 0.04$ $\mathrm{g} / \mathrm{g} \mathrm{BW}$ (body weight) for RI $\alpha \mathrm{B}-\mathrm{ON}$ mice; $p<0.05$ ). Accumulated food intake over $7 \mathrm{~d}$ is shown in Figure $2 I$ and $J$. We conclude that $\mathrm{RI} \alpha \mathrm{B}-\mathrm{ON}$ mice are hypophagic and that they are sensing their deficient energy storage based on the elevated orexigenic hypothalamic peptides, AgRP and NPY, and decreased anorexigenic, POMC, but they are not motivated to consume more food.

\section{$\mathrm{RI} \alpha \mathrm{B}-\mathrm{ON}$ mice are resistant to diet-induced hyperphagia} and obesity

High-fat diet (HFD)-induced hyperphagia as measured by increased caloric intake was observed in control mice as expected
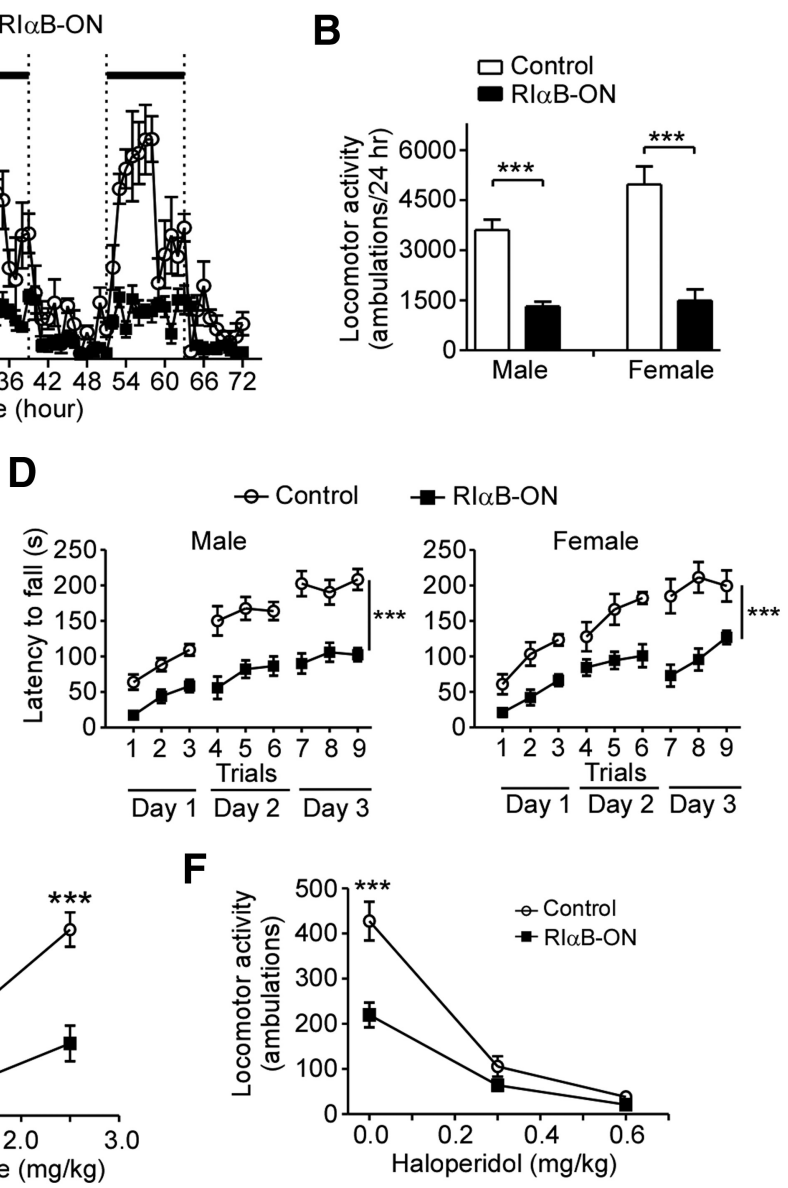

Figure 4. $\quad$ Rl $\alpha$ B-ON mice exhibit defects in locomotor activity. $\boldsymbol{A}$, Seventy-two hour locomotion traces of female control and Rl $\alpha$ B-ON mice ( $n=8-10$ for each group, $p<0.0001$ between genotypes by two-way ANOVA). $D$, Rotarod performance during 列 and $n=8$ for each group. $p<0.001$ between genotypes for both drug treatments by repeated measures two-way ANOVA. * $p<$ $0.05,{ }^{* *} p<0.001$ between genotypes by Bonferroni post-tests.

but absent in RI $\alpha$ B-ON mice (Fig. 3A). The preference for a HFD, however, was similar between RI $\alpha \mathrm{B}-\mathrm{ON}$ and control mice, with both preferring the HFD when HFD and regular chow were presented simultaneously (Fig. 3B). This suggests that the lack of HFD-induced hyperphagia in $\mathrm{RI} \alpha \mathrm{B}-\mathrm{ON}$ mice cannot be explained by their indifference to the HFD.

HFD-induced weight gain was prominent in control mice after 4 weeks of HFD feeding but absent in $\mathrm{RI} \alpha \mathrm{B}-\mathrm{ON}$ mice. Compared with the weight gain of chow-fed mice during the same period (16-20 weeks of age), HFD increased weight gain in control mice but had no effect on weight gain in $\mathrm{RI} \alpha \mathrm{B}-\mathrm{ON}$ mice (Fig. 3C). Fat pad weight (Fig. 3D) and serum leptin levels (Fig. $3 E$ ) were dramatically increased by HFD feeding in control mice but not in $\mathrm{RI} \alpha \mathrm{B}-\mathrm{ON}$ mice compared with chowfed mice. We also studied fasting-induced hyperphagia and found that the compensatory eating after a $24 \mathrm{~h}$ fast was dramatic in control mice but absent in $\mathrm{RI} \alpha \mathrm{B}-\mathrm{ON}$ mice (Fig. $3 F$ ). Consistent with the feeding behaviors, control mice regained their body weight after $24 \mathrm{~h}$ re-feeding but the $\mathrm{RI} \alpha \mathrm{B}-\mathrm{ON}$ mice regained their weight much more slowly (Fig. 3G). Overall the $\mathrm{RI} \alpha \mathrm{B}-\mathrm{ON}$ mice do not respond with normal enthusiasm for a 

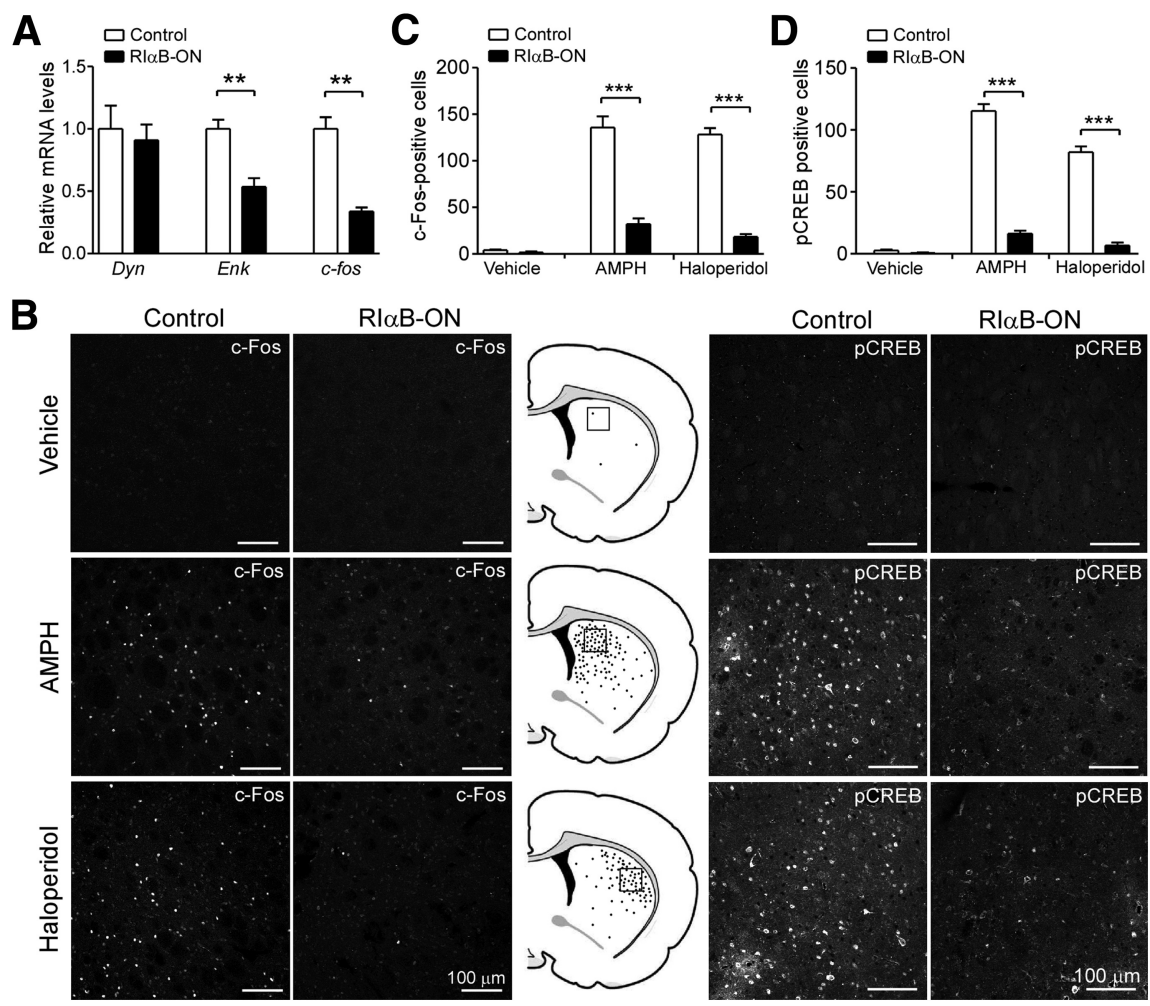

Figure 5. Rl $\alpha \mathrm{B}-\mathrm{ON}$ mice have reduced $\mathrm{pCREB}$ and $\mathrm{c}-\mathrm{Fos}$ induction in striatum in response to dopaminergic drugs. $\boldsymbol{A}$, Relative mRNA levels of dynorphin (Dyn), enkephalin (Enk), and c-fos in the striatum of unstimulated control and Rl $\alpha \mathrm{B}-0 \mathrm{~N}$ mice as determined by $q R T-P C R ; n=3$ for each genotype. $B$, Representative images of $c$-fos and phospho-CREB (S133; $\mathrm{PCREB})$ immunostaining in dorsal striatum $2 \mathrm{~h}$ (for c-fos) or $15 \mathrm{~min}$ (for pCREB) following vehicle, D-amphetamine (AMPH; $5 \mathrm{mg} / \mathrm{kg}$ ), or haloperidol (1 $\mathrm{mg} / \mathrm{kg}$ ) treatment in control and Rl $\alpha \mathrm{B}-0 \mathrm{~N}$ mice. C, Cell counts for c-fos-positive neurons ( $n=3$ animals) in the striatal sections shown in $\boldsymbol{B}$. D. Cell counts for $p$ CREB-positive neurons ( $n=3$ animals) in the striatal sections from mice with treatments as shown in $\boldsymbol{B} .{ }^{* *} p<0.01,{ }^{* * *} p<0.001$ by Student's $t$ tests.

highly palatable diet and show defective compensatory eating after fasting.

\section{RI $\alpha \mathrm{B}-\mathrm{ON}$ mice exhibit impaired locomotor activity}

Nocturnal locomotor activity was greatly decreased in $\mathrm{RI} \alpha \mathrm{B}-\mathrm{ON}$ mice compared with controls (Fig. 4A,B). Exploratory behavior such as increased rearing in response to a novel environment was also attenuated in $\mathrm{RI} \alpha \mathrm{B}-\mathrm{ON}$ mice (Fig. $4 \mathrm{C}$ ). To examine motor coordination and motor learning, we assessed the ability of mice to perform on an accelerating rotarod. $\mathrm{RI} \alpha \mathrm{B}-\mathrm{ON}$ mice were significantly impaired in the task initially and although their performance improved with training they remained significantly deficient compared with control mice (Fig. 4D). The graded improvement of $\mathrm{RI} \alpha \mathrm{B}-\mathrm{ON}$ within each trial and their memory for the task on subsequent days indicate that their learning is not impaired and suggests that their poor performance compared with controls is either due to lack of coordination or decreased incentive to stay on the rotating rod.

Amphetamine treatment causes an acute stimulation of locomotor activity primarily by increasing the release of dopamine and activation of D1R-expressing MSNs (Ferger et al., 1994). We tested whether the $\mathrm{RI} \alpha \mathrm{B}-\mathrm{ON}$ mice would respond to amphetamine in a similar fashion compared with control mice. A low dose of amphetamine ( $1 \mathrm{mg} / \mathrm{kg})$ significantly stimulated locomotion in control mice ( $p=0.05$ compared with vehicle treatment) but had no effect on the activity of RI $\alpha \mathrm{B}-\mathrm{ON}$ mice (Fig. $4 E$ ). With an increased dose of amphetamine $(2.5 \mathrm{mg} / \mathrm{kg})$, both control and $\mathrm{RI} \alpha \mathrm{B}-\mathrm{ON}$ mice increased their locomotor activity by 4 - to 5 -fold although the actual locomotor activity of $\mathrm{RI} \alpha \mathrm{B}-\mathrm{ON}$ mice remained much lower than control mice as shown in Figure $4 E$. The results suggest that $\mathrm{RI} \alpha \mathrm{B}-\mathrm{ON}$ mice have decreased sensitivity to amphetamineinduced locomotor activity. Haloperidol is a D2R antagonist and causes decreased locomotor activity and catalepsy in mice by blocking the basal effects of dopamine on D2R-expressing MSNs. Haloperidol caused a dramatic decrease in locomotor activity at $0.3-0.6 \mathrm{mg} / \mathrm{kg}$ in both control and $\mathrm{RI} \alpha \mathrm{B}-\mathrm{ON}$ mice (Fig. $4 F$ ), suggesting that the acute behavioral response to a D2R antagonist remains intact. Although the fold changes in locomotor activity are similar, it is important to note that the baseline locomotor activity of the RI $\alpha$ B-ON mice was only $~ 50 \%$ of that of WT mice in these experiments.

\section{Induction of c-fos and CREB phosphorylation by dopaminergic drugs is strongly inhibited in $\mathrm{RI} \alpha \mathrm{B}-\mathrm{ON}$ mice \\ We studied striatal gene expression in un-} stimulated mice and found that enkephalin expression (in D2 neurons) was significantly decreased in $\mathrm{RI} \alpha \mathrm{B}-\mathrm{ON}$ mice while dynorphin (in D1 neurons) was not (Fig. 5A). Expression of the immediate early gene c-fos was also greatly decreased in $\mathrm{RI} \alpha \mathrm{B}-\mathrm{ON}$ mice (Fig. $5 A$ ), indicating suppressed basal activation of striatal neurons in these mice. Acute amphetamine treatment increases c-fos expression primarily in D1R neurons (Badiani et al., 1999). In contrast, acute injection of the D2R antagonist, haloperidol, induces c-fos expression in D2R neurons (Bertran-Gonzalez et al., 2008). We speculated that both amphetamine and haloperidol promote $\mathrm{c}$-fos expression by activating the cAMP-PKA pathway in the cell body. In control mice, c-fos immunostaining was significantly increased at $2 \mathrm{~h}$ in the dorsomedial region of the striatum after amphetamine treatment (5.0 $\mathrm{mg} / \mathrm{kg}$ ) and in the dorsolateral region of the striatum after haloperidol treatment $(1.0 \mathrm{mg} / \mathrm{kg}$; Fig. $5 B$, left $)$. However the $\mathrm{RI} \alpha \mathrm{B}-\mathrm{ON}$ mice are deficient in the induction of $\mathrm{c}$-fos by either amphetamine or haloperidol treatment (Fig. $5 B, C$ ). Both drugs significantly altered locomotor activity (data not shown; Fig. $4 E, F)$. We also examined the phosphorylation of the transcription factor, CREB, since CREB is a potential activator of c-fos transcription and a key substrate for PKA. The phosphorylation of CREB in response to both amphetamine and haloperidol was greatly attenuated in the RI $\alpha \mathrm{B}-\mathrm{ON}$ striatum (Fig. $5 B$, right; $D$ ). The decreased expression of c-fos in response to either amphetamine or haloperidol suggests that PKA is inhibited in both D1R and $\mathrm{D} 2 \mathrm{R}$ neurons in RI $\alpha \mathrm{B}-\mathrm{ON}$ mice.

\section{Discussion}

The cAMP-mediated activation of PKA is thought to play a primary role as an effector of dopamine signaling in the striatum, but the role of specific isoforms of PKA has been more difficult to elucidate. The MSNs abundantly express RII $\beta$ and we have shown that this type II RII $\beta$-PKA holoenzyme is localized pri- 
marily to the dendrites of MSNs by interaction with AKAP5 and MAP2 (Weisenhaus et al., 2010). The type I $(\mathrm{RI} \alpha / \beta)$ PKA holoenzyme does not bind to AKAP5 (Herberg et al., 2000) and is thought to localize in the cell body. Striatal MSNs respond to dopamine and dopaminergic drugs with changes in electrical excitability and firing rate as well as changes in gene expression. PKA activation in dendrites is thought to regulate the phosphorylation of ion channels and other postsynaptic targets and modulate the response of MSNs to glutamatergic input from the cortex and thalamus. Sustained induction of cAMP and activation of PKA is also thought to transmit a signal to the cell nucleus that leads to phosphorylation of specific transcription factors and induction of gene expression and long-term changes in MSN function. Since the type I PKA holoenzyme is enriched in the soma, we reasoned that it might play an important role in regulating nuclear events and that the $\mathrm{RI} \alpha$ subunit would act to inhibit free $\mathrm{C}$ subunit and provide a shut-off mechanism.

Dominant-negative mutations in the $\mathrm{RI} \alpha$ subunit were originally selected and characterized in S49 cells that had been mutagenized and selected for resistance to cAMP-mediated growth inhibition (Clegg et al., 1987; Steinberg et al., 1991). These mutations clustered in the cAMP binding domains and prevented cAMP binding and activation of the holoenzyme. We have devised a selective way to inhibit the type I kinase in vivo in a cell type-specific fashion by inserting a dominant-negative mutation directly into the Prkarla allele such that it will only be expressed in the presence of Cre recombinase (Willis et al., 2011). When a mouse that harbors this mutant allele $(\mathrm{RI} \alpha \mathrm{B})$ is mated to a Cre recombinase transgenic, the $\mathrm{RI} \alpha \mathrm{B} / \mathrm{Cre}^{+}$offspring expresses equal levels of both WT and mutant RI $\alpha \mathrm{B}$ mRNA in cell types in which Cre recombination has occurred. This results in a partial reduction of type I kinase activity without significant perturbation of the type II endogenous kinase. When we expressed RI $\alpha \mathrm{B}$ specifically in MSNs with D32-Cre, striatal total PKA activity was reduced by only $10 \%$ but type I PKA activity was reduced by almost $60 \%$ based on in vitro assays. The $\mathrm{RI} \alpha \mathrm{B}$ localized to the cell body as expected and did not disturb the localization or $\mathrm{C}$ subunit binding of RII $\beta$ in dendrites. The mice exhibited a striking phenotype characterized by a decrease in growth (body weight and body length). They are hypophagic and have lost their incentive to overeat when presented with a highly palatable HFD or after fasting. Their nocturnal locomotor activity is profoundly suppressed and both basal and dopaminergic drug-induced gene expression are also inhibited. Amphetamine-stimulated locomotion was blunted suggesting that type I PKA activity in striatal D1R neurons is a regulator of both c-fos induction and the behavioral effects of amphetamine. The suppression of locomotor activity by the D2R antagonist, haloperidol, is more difficult to interpret since the $\mathrm{RI} \alpha \mathrm{B}-\mathrm{ON}$ mice have such low locomotor activity at baseline. Nevertheless, haloperidol further reduced locomotion in the $\mathrm{RI} \alpha \mathrm{B}-\mathrm{ON}$ mice. The $\mathrm{RI} \alpha \mathrm{B}-\mathrm{ON}$ mutation also suppressed CREB phosphorylation and c-fos induction by haloperidol. The results suggest that type I PKA in the cell body of MSNs is preferentially involved in gene expression events but also affects the behavioral response to dopaminergic drugs. RII $\beta$-PKA signaling in the dendrites is essential for the behavioral effect of haloperidol since $\mathrm{RII} \beta \mathrm{KO}$ mice are resistant to haloperidolinduced catalepsy (Adams et al., 1997). The RI $\alpha \mathrm{B}-\mathrm{ON}$ mouse provides a mouse model for studying the physiological role of PKA signaling specifically in the cell body.

Certain aspects of the $\mathrm{RI} \alpha \mathrm{B}-\mathrm{ON}$ phenotype are similar to other mouse lines with impaired dopamine signaling. Mice with targeted mutations in dopamine receptors or the enzymes re-

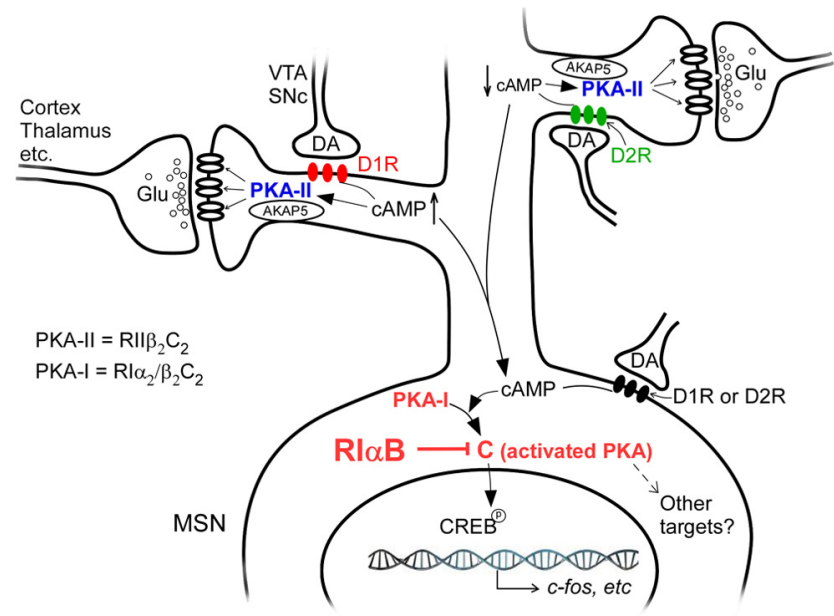

Figure 6. Model for inhibition of PKA signaling by RI $\alpha$ B expression in MSNs. RII $\beta$-PKA is localized to dendrites by binding to AKAP5, while Rl $\alpha$ B protein is mainly concentrated in the soma of MSNs. In the dendrites CAMP production is activated or inhibited by dopamine acting on D1R or D2R dopamine (DA) receptors, respectively. For simplicity a neuron is shown expressing both D1R and D2R, although in most MSNs they are expressed in separate populations. Activated PKA locally phosphorylates substrates such as glutamate (Glu) receptors. The type I $(\mathrm{Rl} \alpha / \beta)$ PKA in the soma could be activated by locally generated cAMP or cAMP diffusing to the soma from dendrites. Dissociated C subunit enters the nucleus and phosphorylates target proteins such as CREB, which then promotes gene expression. We propose that $\mathrm{Rl} \alpha \mathrm{B}$ in the soma inhibits the trafficking of C subunit of PKA into the nucleus and thus impairs gene expression and normal physiological functions of MSN. SNc, substantial nigra compacta; VTA, ventral tegmental area.

quired to produce dopamine exhibit locomotor defects. D1R MSNs and D2R MSNs exert opposing control over locomotor activity; firing of D1R MSNs promotes locomotion while firing of D2R MSNs inhibits locomotion (Bateup et al., 2010; Kravitz et al., 2010). Dopamine positively modulates D1R MSNs but negatively modulates D2R MSNs, thus promoting locomotion by its dual action on both pathways. D1R is positively coupled to the $\mathrm{G}_{\mathrm{s}}$-cAMP-PKA pathway whereas $\mathrm{D} 2 \mathrm{R}$ negatively regulates cAMP-PKA signaling by coupling to $\mathrm{G}_{\mathrm{i}}$. D1R and D2R occupancy is dependent on the dynamic changes in dopamine levels in the synaptic cleft that are regulated by tonic and phasic firing of dopaminergic neurons (Grace and Bunney, 1984a,b; Dreyer et al., 2010; Owesson-White et al., 2012). Phasic dopamine release has been associated with a variety of motivational events (Robinson et al., 2011) and is required for learning about cues associated with rewarding events (Tsai et al., 2009; Zweifel et al., 2009). However, phasic dopamine signaling is not necessary for most motor functions, including rotarod performance. Coordinated movement seems to depend primarily on tonic dopamine signaling (Zweifel et al., 2009). D1R KO mice have decreased locomotor activity in their home cage but increased activity in an open field test (Kobayashi et al., 2004), although a more detailed analysis showed that this increased activity was seen only in a subset of the D1R KO mice (Wall et al., 2011). D2R KO mice have decreased locomotion in both their home cage and in an open field test (Baik et al., 1995; Kobayashi et al., 2004), while rearing in open field was attenuated in both D1R and D2R KO mice (Kobayashi et al., 2004). Dopamine-deficient mice have greatly reduced locomotor activity and die of starvation unless treated with L-DOPA (Zhou and Palmiter, 1995). The RI $\alpha$ B-ON mice have a $60-70 \%$ reduction in overall locomotor activity and are also significantly impaired on a rotarod test of motor coordination and 
learning; these locomotor phenotypes are quite similar to that observed for D2R KO mice (Baik et al., 1995). The feeding and energy homeostasis phenotypes of the RI $\alpha \mathrm{B}-\mathrm{ON}$ mice also share similarities with mice harboring mutations in the dopamine response pathways of the striatum. Both D1R and D2R KO mice are hypophagic and have decreased body weight (Baik et al., 1995; Smith et al., 1998), although in the case of the D1R KO part of this effect may be due to loss of D1R in the gastrointestinal tract (Kobayashi et al., 2004).

The model depicted in Figure 6 proposes that type II PKA $(\mathrm{RII} \beta)$ activation by cAMP mediates the acute effects of dopamine at the postsynaptic terminals; sustained increases in cAMP lead to diffusion of cAMP to the cell body, activation of type I PKA, and translocation of $\mathrm{C}$ subunit to the nucleus where it phosphorylates transcription factors like CREB and activates gene expression. cAMP-synthesized in dendrites has been shown to diffuse into the cell body and activate PKA (Bacskai et al., 1993; Nikolaev et al., 2004). The type I $(\mathrm{RI} \alpha / \beta)$ regulatory subunits in the cell body are proposed to act in part to turn off the signal by recombining with free $\mathrm{C}$ subunits as they are actively removed from the cell nucleus by the nuclear export pathway. The type I PKA could also respond to changes in cAMP generated by ligandactivated D1R or D2R localized on the cell body. When we express $\mathrm{RI} \alpha \mathrm{B}$ in the MSNs it acts as a more durable inhibitor of $\mathrm{C}$ subunit in the cell body and therefore interferes with gene regulation by attenuating the signal from the dendrites and inhibiting direct activation of PKA by cAMP generated in the cell body. Chronic inhibition of PKA-mediated gene regulation in the striatum leads to the hypophagia and reduced locomotor activity seen in $\mathrm{RI} \alpha \mathrm{B}-\mathrm{ON}$ mice. Our model seeks to explain the interaction between dendritic PKA, which is primarily type II and cytoplasmic PKA and which is primarily type I in neurons. The dramatic phenotype of RI $\alpha \mathrm{B}-\mathrm{ON}$ mice suggests that although the level of cytoplasmic type I kinase constitutes only a small percentage of the total cellular PKA in MSNs it plays a significant role in the regulation of gene expression and overall function in these neurons.

\section{References}

Adams MR, Brandon EP, Chartoff EH, Idzerda RL, Dorsa DM, McKnight GS (1997) Loss of haloperidol induced gene expression and catalepsy in protein kinase A-deficient mice. Proc Natl Acad Sci U S A 94:12157-12161. CrossRef Medline

Bacskai BJ, Hochner B, Mahaut-Smith M, Adams SR, Kaang BK, Kandel ER, Tsien RY (1993) Spatially resolved dynamics of cAMP and protein kinase A subunits in Aplysia sensory neurons. Science 260:222-226. CrossRef Medline

Badiani A, Oates MM, Day HE, Watson SJ, Akil H, Robinson TE (1999) Environmental modulation of amphetamine-induced c-fos expression in D1 versus D2 striatal neurons. Behav Brain Res 103:203-209. CrossRef Medline

Baik JH, Picetti R, Saiardi A, Thiriet G, Dierich A, Depaulis A, Le Meur M, Borrelli E (1995) Parkinsonian-like locomotor impairment in mice lacking dopamine D2 receptors. Nature 377:424-428. CrossRef Medline

Bateup HS, Santini E, Shen W, Birnbaum S, Valjent E, Surmeier DJ, Fisone G, Nestler EJ, Greengard P (2010) Distinct subclasses of medium spiny neurons differentially regulate striatal motor behaviors. Proc Natl Acad Sci U S A 107:14845-14850. CrossRef Medline

Beaulieu JM, Gainetdinov RR (2011) The physiology, signaling, and pharmacology of dopamine receptors. Pharmacol Rev 63:182-217. CrossRef Medline

Beaulieu JM, Gainetdinov RR, Caron MG (2007) The Akt-GSK-3 signaling cascade in the actions of dopamine. Trends Pharmacol Sci 28:166-172. CrossRef Medline

Bertran-Gonzalez J, Bosch C, Maroteaux M, Matamales M, Hervé D, Valjent E, Girault JA (2008) Opposing patterns of signaling activation in dopa- mine D1 and D2 receptor-expressing striatal neurons in response to cocaine and haloperidol. J Neurosci 28:5671-5685. CrossRef Medline

Bogush AI, McCarthy LE, Tian C, Olm V, Gieringer T, Ivkovic S, Ehrlich ME (2005) DARPP-32 genomic fragments drive Cre expression in postnatal striatum. Genesis 42:37-46. CrossRef Medline

Brandon EP, Logue SF, Adams MR, Qi M, Sullivan SP, Matsumoto AM, Dorsa DM, Wehner JM, McKnight GS, Idzerda RL (1998) Defective motor behavior and neural gene expression in RIIbeta-protein kinase A mutant mice. J Neurosci 18:3639-3649. Medline

Burton KA, McDermott DA, Wilkes D, Poulsen MN, Nolan MA, Goldstein M, Basson CT, McKnight GS (2006) Haploinsufficiency at the protein kinase A RI alpha gene locus leads to fertility defects in male mice and men. Mol Endocrinol 20:2504-2513. CrossRef Medline

Clegg CH, Correll LA, Cadd GG, McKnight GS (1987) Inhibition of intracellular cAMP-dependent protein kinase using mutant genes of the regulatory type I subunit. J Biol Chem 262:13111-13119. Medline

Drago J, Gerfen CR, Lachowicz JE, Steiner H, Hollon TR, Love PE, Ooi GT, Grinberg A, Lee EJ, Huang SP (1994) Altered striatal function in a mutant mouse lacking D1A dopamine receptors. Proc Natl Acad Sci U S A 91:12564-12568. CrossRef Medline

Dreyer JK, Herrik KF, Berg RW, Hounsgaard JD (2010) Influence of phasic and tonic dopamine release on receptor activation. J Neurosci 30:1427314283. CrossRef Medline

Ferger B, Kropf W, Kuschinsky K (1994) Studies on electroencephalogram (EEG) in rats suggest that moderate doses of cocaine or d-amphetamine activate D1 rather than D2 receptors. Psychopharmacology 114:297-308. CrossRef Medline

Grace AA, Bunney BS (1984a) The control of firing pattern in nigral dopamine neurons: burst firing. J Neurosci 4:2877-2890. Medline

Grace AA, Bunney BS (1984b) The control of firing pattern in nigral dopamine neurons: single spike firing. J Neurosci 4:2866-2876. Medline

Greengard P (2001) The neurobiology of slow synaptic transmission. Science 294:1024-1030. CrossRef Medline

Herberg FW, Maleszka A, Eide T, Vossebein L, Tasken K (2000) Analysis of A-kinase anchoring protein (AKAP) interaction with protein kinase A (PKA) regulatory subunits: PKA isoform specificity in AKAP binding. J Mol Biol 298:329-339. CrossRef Medline

Howe DG, Clarke CM, Yan H, Willis BS, Schneider DA, McKnight GS, Kapur RP (2006) Inhibition of protein kinase A in murine enteric neurons causes lethal intestinal pseudo-obstruction. J Neurobiol 66:256-272. CrossRef Medline

Huseby S, Gausdal G, Keen TJ, Kjaerland E, Krakstad C, Myhren L, Brønstad K, Kunick C, Schwede F, Genieser HG, Kleppe R, Døskeland SO (2011) Cyclic AMP induces IPC leukemia cell apoptosis via CRE-and CDKdependent Bim transcription. Cell Death Dis 2:e237. CrossRef Medline

Kobayashi M, Iaccarino C, Saiardi A, Heidt V, Bozzi Y, Picetti R, Vitale C, Westphal H, Drago J, Borrelli E (2004) Simultaneous absence of dopamine D1 and D2 receptor-mediated signaling is lethal in mice. Proc Natl Acad Sci U S A 101:11465-11470. CrossRef Medline

Kravitz AV, Freeze BS, Parker PR, Kay K, Thwin MT, Deisseroth K, Kreitzer AC (2010) Regulation of parkinsonian motor behaviours by optogenetic control of basal ganglia circuitry. Nature 466:622-626. CrossRef Medline

Madisen L, Zwingman TA, Sunkin SM, Oh SW, Zariwala HA, Gu H, Ng LL, Palmiter RD, Hawrylycz MJ, Jones AR, Lein ES, Zeng H (2010) A robust and high-throughput Cre reporting and characterization system for the whole mouse brain. Nat Neurosci 13:133-140. CrossRef Medline

Myers MG, Cowley MA, Münzberg H (2008) Mechanisms of leptin action and leptin resistance. Annu Rev Physiol 70:537-556. CrossRef Medline

Nikolaev VO, Bünemann M, Hein L, Hannawacker A, Lohse MJ (2004) Novel single chain cAMP sensors for receptor-induced signal propagation. J Biol Chem 279:37215-37218. CrossRef Medline

Nolan MA, Sikorski MA, McKnight GS (2004) The role of uncoupling protein 1 in the metabolism and adiposity of RII beta-protein kinase A-deficient mice. Mol Endocrinol 18:2302-2311. CrossRef Medline

Owesson-White CA, Roitman MF, Sombers LA, Belle AM, Keithley RB, Peele JL, Carelli RM, Wightman RM (2012) Sources contributing to the average extracellular concentration of dopamine in the nucleus accumbens. J Neurochem 121:252-262. CrossRef Medline

Palmiter RD (2008) Dopamine signaling in the dorsal striatum is essential for motivated behaviors: lessons from dopamine-deficient mice. Ann N Y Acad Sci 1129:35-46. CrossRef Medline 
Robinson DL, Zitzman DL, Williams SK (2011) Mesolimbic dopamine transients in motivated behaviors: focus on maternal behavior. Front Psychiatry 2:23. CrossRef Medline

Smith DR, Striplin CD, Geller AM, Mailman RB, Drago J, Lawler CP, Gallagher M (1998) Behavioural assessment of mice lacking D1A dopamine receptors. Neuroscience 86:135-146. CrossRef Medline

Steinberg RA, Gorman KB, Ogreid D, Døskeland SO, Weber IT (1991) Mutations that alter the charge of type I regulatory subunit and modify activation properties of cyclic AMP-dependent protein kinase from S49 mouse lymphoma cells. J Biol Chem 266:3547-3553. Medline

Tsai HC, Zhang F, Adamantidis A, Stuber GD, Bonci A, de Lecea L, Deisseroth $\mathrm{K}$ (2009) Phasic firing in dopaminergic neurons is sufficient for behavioral conditioning. Science 324:1080-1084. CrossRef Medline

Valjent E, Bertran-Gonzalez J, Hervé D, Fisone G, Girault JA (2009) Looking BAC at striatal signaling: cell-specific analysis in new transgenic mice. Trends Neurosci 32:538-547. CrossRef Medline

Veugelers M, Wilkes D, Burton K, McDermott DA, Song Y, Goldstein MM, La Perle K, Vaughan CJ, O'Hagan A, Bennett KR, Meyer BJ, Legius E, Karttunen M, Norio R, Kaariainen H, Lavyne M, Neau JP, Richter G, Kirali K, Farnsworth A, et al. (2004) Comparative PRKAR1A genotypephenotype analyses in humans with Carney complex and prkarla haploinsufficient mice. Proc Natl Acad Sci U S A 101:14222-14227. CrossRef Medline

Wall VZ, Parker JG, Fadok JP, Darvas M, Zweifel L, Palmiter RD (2011) A behavioral genetics approach to understanding D1 receptor involvement in phasic dopamine signaling. Mol Cell Neurosci 46:21-31. CrossRef Medline

Weisenhaus M, Allen ML, Yang L, Lu Y, Nichols CB, Su T, Hell JW, McKnight GS (2010) Mutations in AKAP5 disrupt dendritic signaling complexes and lead to electrophysiological and behavioral phenotypes in mice. PLoS One 5:e10325. CrossRef Medline

Willis BS, Niswender CM, Su T, Amieux PS, McKnight GS (2011) Cell-type specific expression of a dominant negative PKA mutation in mice. PLoS One 6:e18772. CrossRef Medline

Woodford TA, Correll LA, McKnight GS, Corbin JD (1989) Expression and characterization of mutant forms of the type I regulatory subunit of cAMP-dependent protein kinase. The effect of defective cAMP binding on holoenzyme activation. J Biol Chem 264:13321-13328. Medline

Zheng R, Yang L, Sikorski MA, Enns LC, Czyzyk TA, Ladiges WC, McKnight GS (2013) Deficiency of the RIIbeta subunit of PKA affects locomotor activity and energy homeostasis in distinct neuronal populations. Proc Natl Acad Sci U S A 110:E1631-1640. CrossRef Medline

Zhou QY, Palmiter RD (1995) Dopamine-deficient mice are severely hypoactive, adipsic, and aphagic. Cell 83:1197-1209. CrossRef Medline

Zweifel LS, Parker JG, Lobb CJ, Rainwater A, Wall VZ, Fadok JP, Darvas M, Kim MJ, Mizumori SJ, Paladini CA, Phillips PE, Palmiter RD (2009) Disruption of NMDAR-dependent burst firing by dopamine neurons provides selective assessment of phasic dopamine-dependent behavior. Proc Natl Acad Sci U S A 106:7281-7288. CrossRef Medline 